\title{
Immature Peripheral Alpha/Beta Cell of Cytotoxic Type
}

National Cancer Institute

\section{Source}

National Cancer Institute. Immature Peripheral Alpha/Beta Cell of Cytotoxic Type. NCI Thesaurus. Code C38327.

A cell derived from stem cells in the bone marrow. It is a maturing $T$ lymphocyte that expresses an alpha-beta antigen specific surface receptor (TCR) and the CD8 surface marker. These cells mature in the thymus. 